\title{
In Fluence of budgeting system on Entrepreneurial Business performance: perspective of Small business Owner in lagos state Nigeria
}

\author{
Akande, Olusola. $\mathrm{O}^{1}$ and Yinus Oluwaseun ${ }^{2}$ \\ Department of Management and Accounting, Faculty of Management Sciences \\ Ladoke Akintola University of Technology, Ogbomoso, Oyo State, Nigeria.
}

\begin{abstract}
Budgeting has been described to be significant and basic to Business Financial performance. Small businesses have become a crucial segment and a major section of private sector in developing countries. The degree to which budgetary system influences financial performance of small businesses is worthy of exploration in developing economies like Nigeria. This research attempts to ascertain the comprehensiveness of budgeting practices adopted by entrepreneurs in Lagos state and investigate whether budgetary system influences Small Business financial performance. Multi-stage probability sampling technique was used. A sample of (120) one hundred and twenty entrepreneurs were selected from a list of 4,585 registered SMEs in Lagos state as at the end of March, 2014 (www.moneyhub.net.com) out of which 104 (86\%) usable questionnaires were analyzed, summarized, and interpreted accordingly with the aid of descriptive statistical technique using simple percentages. A non-parametric statistical test; Chi-square was used to test the formulated hypothesis. The result of the tested hypothesis shows that there is a significant relationship between budgeting practices and small business financial performance. It is suggested that entrepreneurs must have a clear financial goal in mind, which will assists in shaping a broader business strategy for the year.
\end{abstract}

Keywords:- SMEs; Budgeting; Business Performance; Entrepreneurial Skill; Entrepreneurs

\section{INRODUCTION}

In Nigeria $75 \%$ of the private sector is dominated by Entrepreneur of Small and Medium Enterprises (SMEs) reiterating that Organized Private Sector (OPS) is the engine of growth and creator of wealth and employment (Adelaja, 2006). Therefore the contribution of entrepreneurs to a nation's economy cannot be overemphasized. For instance Akande (2011) suggested that if the first Millennium Development Goal adopted by the United Nations Millennium Summit in year 2000 (which is eradication of poverty and hunger before year 2015 ) is to be achieved, emphasis on Entrepreneur development will go a long way at achieving this. Small and medium enterprises that have been described as the nerve of a nation economy are suffering from poor funding (Basu, Balvy and Yulek, 2004; Oladejo, 2008). This might not be unconnected with poor financial planning and strategy.

Studies have shown that small businesses in many countries are mechanisms for stimulating indigenous entrepreneurship, enhancing greater employment opportunities per unit of capital invested and aiding the development of local technology (Sule, 1986; World Bank, 1995; Chen and Williams, 1999; Akande, 2005). Furthermore, Adelaja (2006:3) averred that interaction between Small and Medium Enterprises (SMEs) operators is a factor for the development of SME's in Nigeria. Anwatu (2006:3) said that $75 \%$ of the private sector is dominated by Small and Medium Enterprises (SMEs) reiterating that Organized Private Sector (OPS) is the engine of growth and creator of wealth and employment. The Nigeria Chamber of Commerce, Industry, Mines and Agriculture (NACCIMA 2006:14) argued that small scale enterprises SSEs are the vehicle for rapid industrialization and development of any nation. Eke (2007:31) argued that MSMEs account for over Ninety three percent of the total entrepreneurs in Nigeria. In Nigeria, as well as in most other countries of the world, small and medium-sized companies (SMEs) represent the vast majority (99\%) of all enterprises (OECD,2004). Their contribution to economic growth, job creation and innovation is widely recognized (Audretsch and Keilbach, 2004; Van Stel et al., 2005). They are known all over the world to account for substantial proportion of industrial build up in many developed nations. The nature of their operations, capital requirement for settingup and the employment generation effects made them the focus of most developmental efforts in less developed countries. However, many of them do not survive their first years in business (Storey 1994; Almus, 2004), and as such, are not able to provide these benefits to the society in which they are located. An overview of the performance of the micro enterprises in Nigeria shows that past policies made limited impact on the Micro enterprises sector as observed Akanji (2006). 
However while contributions of small business to development are generally acknowledged, entrepreneurs face many obstacles that limit their long term performance and invariably, their development and growth (Akande, 2011). Taking advantage from budgetary system is expected to influence the performance of entrepreneur businesses. For instance over the past two decades, the word budget has become common in managerial discourse. Most establishments find it necessary to prepare budgets and institute budgetary control for the purpose of translating policies, coordinating activities, as well as ensuring financial controls in order to achieve the possible results of their objective. Budget is a comprehensive, formal plan that estimates the probable expenditure for an Entrepreneur over a specific period). This has been an important subject in the literature of accounting for a long time and one of the basic significance of the performance of business firms (Eker, 2006). The activities of business organisation to be financed through the budget are usually many and diverse. In total, they affect the profitability and ability of business organisation to achieve its stated objectives. It is essential that consideration is given during the budget process to the claims of all the units and sections and a comprehensive financial plan developed which then represents the action programmers of the entrepreneur of a Firm.

Evidence from the literature shows budgeting influence performance of any business However, the argument is that though this effect cannot be ruled out, there is a possibility whether the way of linkage is negative or positive. Hence, this study attempts to explore the effect of budgeting on entrepreneur business performance and the correlation between budget practices and entrepreneur performance.

\section{Statement of the problem}

Inadequate funding of business is a core problem facing by Nigeria entrepreneurs. The process of sourcing for funds as well as the effective utilization and efficient management of the funds constitute major challenges for Entrepreneur (Okafor, 2012). Over the years, there has been a significant increase in government effort to promote the financing of businesses by initiating policies which help entrepreneurs to source funds for business operations. Nigerian banks can access loan able funds from government and international financing institutions like the World Bank which uses the Central Bank of Nigeria (CBN) as the arrow head for on-lending to entrepreneurs. In spite of the various sources of fund made available to them, accessibility to both short-term and long term credits from banks has not been easy for entrepreneur because of the poor risk perception which providers of fund belief in. The poor risk perception is expected to be reduced if qualitative and qualitative financial information details of entrepreneur can be ascertained in term of budgeting, adequate collaterals provided and effective banking relationship established as averred Okafor, (2012).

Furthermore, budgeting and budgetary control is important tools that assist businesses in the performance process to achieve predetermined objectives. Also part of the challenges facing majority of entrepreneurs in Nigeria is lack of involvement of well trained professionals. It has been noted that the failure to effectively discharge of broad financial management functions have contributed largely to global financial crisis.

The argument of Okafor, (2012) that distinction between successful and failed entrepreneur lie in their ability to manage the pre existing fund through effective budgeting and budgetary control calls for more empirical approach to measure budgeting impact on small business performance. The influence of budgeting on entrepreneurial performance has not been greatly explored in Nigeria. Few studies focus entrepreneurship growth while more on Small and medium scale enterprises (SMEs) financing (Asaolu, 2004; Akintoye and Oladejo, 2008) thus making for the relevance of the current study aiming at investigating the effect of budgeting on entrepreneur business performance. Specifically, the study will answer the following research questions:

- Does Budgeting influence entrepreneur business performance?

- What are the obstacles that limit Entrepreneur long term performance?

- Is there any relationship between budgeting process and Entrepreneur performance?

\section{Hypotheses of the study}

The hypotheses for this study are stated in the null form as follows:

$\mathrm{H}_{0}$ : there is no relationship between budgeting process and entrepreneur business performance

\section{Literature Review and Conceptual Explanation}

\section{Budgeting Theory and Entrepreneur}

Danielson and Scott (2006) supported a simple rule managers can use to make capital budgeting decisions: Invest in all positive net present value projects, and reject those with a negative net present value. By following this rule, capital budgeting theory says firms will make the set of investment decisions that will maximize shareholder wealth. And, because net present value is a complete measure of a project's contribution to shareholder wealth, there is no need for the firm to consider alternative capital budgeting tools, such as payback period or accounting rate of return.Yet, Entrepreneur often operate in environments that do not satisfy 
the assumptions underlying the basic capital budgeting model. And, Many Business Organisation may not be able to make reliable estimates of future cash flows, as required in discounted cash flow analysis.

In capital budgeting assumptions and Entrepreneur, Capital budgeting theory typically assumes that the primary goal of an Entrepreneur is to maximize Business value. In addition, the Business is assumed to have access to perfect financial markets, allowing it to finance all value-enhancing projects. When these assumptions are met, Entrepreneur can separate investment and financing decisions, and should invest in all positive net present value projects..There are at least three reasons to question the applicability of this theory to Entrepreneur. First, wealth maximization may not be the objective of every Business. An entrepreneur may establish a firm as an alternative to unemployment, as a way to avoid employment boredom (i.e., as a life-style choice), or as a vehicle to develop, manufacture, and market inventions. In each case, the primary goal of the entrepreneur may be to maintain the viability of the firm, rather than to maximize its value.

Second, Entrepreneurs have limited management resources, and lack expertise in finance and accounting. Because of these deficiencies, they may not evaluate projects using discounted cash flows. The final impediment is capital market imperfections, which constrain the financing options for small firms. Some cannot obtain bank loans, because of their information-opaqueness and lack of strong banking relationships. Access to public capital markets can be expensive for certain small firms, and impossible for others. These capital constraints can make it essential for Entrepreneur to maintain sufficient cash balances, in order to respond to potentially profitable investments as they become available. Thus, capital constraints provide small privately held firms with a legitimate economic reason to be concerned about how quickly a project will generate cash flows (i.e., the payback period).

\section{Entrepreneurs and Small Business Failure}

Researchers have identified lack of access to external finance and weak capital base, inexperience in the field of business, particularly lack of technical knowledge plus inadequate managerial skills, lack of planning and lack of market research as causes of small business failure (Akande, 2010. There is increased rate in business failure despite all the supports and incentives as most business rarely survived their first year in operation. Poor business management, restrictive banking legislation, high interest charges and imperfections in the operation of market mechanism are stumbling blocks to the finance of small and medium Enterprises (SMEs) in Nigeria and have been described to be the major causes of failure for small businesses. Poor measure of financial performance is a problem that has been overlooked in the past years.

For instance Sarapaivanich (2003) commented that even though entrepreneurs play an increasingly important role in providing new products and employment opportunities, they encountered many difficulties, especially financing, Most Entrepreneur frequently lack access to institutional credit, causing them to encounter high financing costs and high failure rates. Akande (2011) revealed that Small business has failed in the past for ignoring the vital measurement variables and factors for performance. Despite the increased

number of small business in Nigeria the rate of business failure is alarming. Study revealed that poor record keeping of their financial performance and lack of basic business management experience and skills are major contributors to failure of small business.

\section{Entrepreneurial Skills and Entrepreneur Development}

Entrepreneurship is the manifest ability and willingness of individual on their own, in terms, within and outside existing organization to perceive and create new economic opportunities and also to introduce their ideas in the market, in the pace of uncertainty and other obstacles by making decisions on locations, forms and the use of resources and institutions. Essentially, entrepreneurship is a behavioural characteristic of persons. It should be noted that entrepreneurship is not an occupation and that entrepreneurs are not a well-defined occupational class of persons. Even obvious entrepreneurs may exhibit their entrepreneurship only during a certain phase of their career and or concerning a certain part of their activities/Entrepreneurial skills compares favourably with the basic skills required for starting, developing, financing and marketing business enterprises opined. Furthering this, entrepreneur is to start and successfully manage a business in a competitive environment. Studies have been conducted on the implication of entrepreneurial skills to business performance. However most of the studies were outside Nigeria which has its own peculiarities. The relationship between entrepreneurship skill and Entrepreneur performance, using person product moment correlation and Regression Analysis, shows that out of the four entrepreneurial skills like business management, financial management, marketing and record keeping skills, the business management skill contributed more than others and that the financial management skill alongside increased the contribution. There are three fundamental propositions about entrepreneur skills thus; entrepreneur are successful to the extent that they have the necessary skills, entrepreneurs come to entrepreneurship at different level of skills and that entrepreneurial skills can be developed. 


\section{Budgeting Skill as an Entrepreneurial Skill}

A budget is a formal expression of plans by management in both quantitative and monetary terms covering various business activities, and aimed at assisting management towards the achievement of organizational objectives. A budget is thus a standard with which to measure the actual achievement of people, departments, firm's e.t.c. it is a comprehensive plan in the firm's expectations in the future. It is the plan of the firm's expectations in the future. It is comprehensive plan in the sense that all activities and operations are considered when it is prepared. Budgets are indeed prepared for various segment of the enterprise, but they are the component of the total budget - the master budget. The budget plan for and quantify revenues and expenses of firm's operation in financial terms. Enya (2012). According to Ogundana (2012), budgeting is the financial translation of the programmed of measures, activities and projects, a good portion of which can be technical in nature. Encyclopaedia for Business sees budget as a comprehensive, formal plan that estimates the probable expenditures and income for an organization over a specified period.

From the above definition, budget can be viewed as a futuristic plan which shows the organizational goals and objectives in monetary terms and the assignment of these objectives to the active members of the organization .in achieving these the Jan Barned (2009) suggested that good budget require Preparation against strategic goals set and approved by the board of management committee, Budgeted timeline aligned to the preparation of financial statements, Regular comparison of budgets against actual financial results as disclosed in the financial statement and Scope for amending activities and targets where actual results indicate that budgeted outcomes will not be me

\section{Business planning versus Budgeting}

Yang Qi (2010) commented that business planning, as described by several scholars in a similar way in the past, is, in general, the conscious determination of courses of action to achieve preconceived objectives. It is based on what is known about the present business environment of that future business. Rather than being a fixed document, a business plan must be flexible enough to change to suit the current environment. It must be constantly reassessed to adapt to changing market conditions such as new competition, price changes, personnel availability, and so on. In contrast to business planning, budgeting underlines predicting and quantifying the future in financial terms and predicting the future needs for finance. Therefore, budgeting is situated between the disciplines of finance and planning. Budgeting data are the most tangible decision causes considered by decision makers. there is a link between budgeting and operational planning and a link between budgeting and strategic planning. However, operational planning, strategic planning, and budgeting are three different concepts with different characteristics. Operational planning is characterized as a wide diversity of practices in different organizations. Strategic planning is an irregular activity that takes place in the higher echelons of an organization. Whereas budgeting as an accounting-based system shows a regular and routine pattern common to all Businesses.

\section{Business Performance}

Ogundana (2012) stated that the concept of performance is used to determine the success of a business entity whether small or big. In 1999, the organization for economic cooperation and development (OECD) issued a document emphasizing that corporations should be run, first and foremost, in the interest of shareholders. This view of OECD is justified by two hundred years of research in economy and finance. It becomes obvious that the financial nature of performance is preferred. The International Accounting Standard Board (IASB) conceptual framework specifies that frequently, profit is used as a measure of performance. This is further confirmed by a study conducted on companies' financial performance. Five representative measures are pointed out as Net Income, Operating Income, Operating Cash flow, Residual income, and Added value. These elements are directly related to the measurement of profit for investors. One of the modalities for encouraging individuals and organizations to invest in equity dominated capital market instruments is the dissemination of projections about the future performance of a firm and as such performance is usually measured in term of earnings, profitability and dividend. business performance can be measured in term of Business size, employment Capacity, turnover, capital base and profitability. Usually the profit is calculated as the net of turnover and associated cost.

\section{Usefulness of Budgeting In Measuring Financial Performance}

Budget is the most effective way to control cash-flow because it allows investments in new opportunities at the appropriate time. If budget is based on business plan, a financial action plan is created and this can serve useful functions particularly if the budget is revised regularly as part of annual planning cycle. Intelligent budgeting incorporates good business judgment in the review and analysis of past trends and data pertinent to the business. This information assists a company in decisions relating to the type of business organization needed, the amount of money to be invested, the type and number of employees to hire (staffing 
plans) and the marketing strategies required. This is because the company usually devises both long-term and short-term plans to implement its strategies and to conduct an ongoing evaluation of its performance.

The budget can provide the basis for detailed sales targets, inventory production, cash investment or borrowing and capital expenditure. Budgets allow managers to provide forward looking guidance to investors and creditors. It is also necessary to convince banks and other lenders to extend credit. A budget can be instrumental in identifying constraints and bottle necks. Managers can learn well in advance of looming production and distribution bottlenecks and the knowledge of these problems helps in resolving or avoiding them. Because the budget is a blue print and a roadmap, it alerts managers to variations from expectations which are a cause for concern. Managers can then revise their immediate plans. Also, in preparing budget, managers are compelled to consider all aspects of a company's internal activities, hence the act of making estimates about future economic conditions and about future economic conditions and about the company's ability to respond to them forces managers to synthesize the external economic environment with their internal goals and objectives.

Finally, if used wisely, budgeting process increases management's ability to deploy resources more efficiently and effectively and to introduce modifications to the plan in a timely manner.

\section{Methodology}

The study made use of cross-sectional survey design. The study area was Lagos, Nigeria, Lagos was selected because is a commercial nerve centre with $2^{\text {nd }}$ largest population in Nigeria (population Census Report 2006). Also, majority of registered businesses that could be used for the study were located in this area. multistage probability sampling technique was used, in which Lagos state was stratified into three geo political zone (Lagos-East, Lagos-Central and Lagos-West) from which the sample of various Owner of small medium scale enterprises(Entrepreneur) was drawn through the simple random sampling procedure. a sample of (120) One hundread and Twenty Entrepreneur were selected from a list of 4,585 registered SMEs in Lagos state as at the end of March, 2014 (www.moneyhub.net.com). The return rate for completed questionnaire was 86 percent as we were able to get back 104 usable questionnaires out of 120 personally administered to our respondents which were employed for final analysis in this study. Data collected from the questionnaire were analyzed, summarized, and interpreted accordingly with the aid of descriptive statistical technique using simple percentages. A non-parametric statistical test; Chi-square was used to test the formulated hypothesis. Symbolic representation of chi-square is given below: $\mathrm{X}^{2}=\sum\left(\mathrm{f}_{\mathrm{o}}-\mathrm{f}_{\mathrm{e}}\right)^{2}<$ Where $\mathrm{X} 2=$ The output of the Chi-square, $\mathrm{F}_{\mathrm{o}}=$ Frequency observed $\mathrm{F}_{\mathrm{e}}=$ Frequency Expected

The test adopted 95 confidence level where the degree of Freedom is determined using (r-1)(c-1) with $r=$ row total, $c=$ column total and level of significance $=0.05$, Critical region $=X^{2} t(0.05,(r-1)(c-1)$, The basis for rejection or acceptance of null and alternate hypothesis is as follows, If $\mathrm{X}^{2} \mathrm{t}>\mathrm{X}^{2}$ while $\mathrm{X}_{\mathrm{c}}^{2}$ represent Chi-square calculated Accept Ho, otherwise when $X^{2} c>X^{2} t$ reject Ho, $X^{2}$ t represents chi-square tabulated

\section{Result and discussion}

The study examines how entrepreneurs view budgeting as business performance enhancing factor and investigates the extent to which budgeting planning has been able to influence entrepreneur operational activities. Simple percentage analysis was employed and non-parametric statistical test such as chi-square was also used to test the formulated hypothesis. Findings from the data analysis and hypothesis tested are presented below.

From the table above it can be seen that $85.58 \%$ agreed that Budgeting process is relevant to Entrepreneur business, $8.65 \%$ disagreed while $5.77 \%$ were undecided. Furthermore, $84.61 \%$ agreed that business regularly evaluate the effectiveness of budgeting process while $12.5 \%$ disagreed and $2.88 \%$ were undecided. 76.96\% agree that Budgeting process positively Influence Business Financial performance, 15.39\% disagreed while $7.65 \%$ were neutral. Also $66.35 \%$ agree that budget is standard with which to measure the actual achievement of Entrepreneurial,23.07 disagreed while $10.57 \%$ were neutral. Finally $75.96 \%$ agreed that budgeting process is not so important in the financial performance of the business, $19.71 \%$ disagreed while $5.77 \%$ were neutral. The overall results from the table also buttressed significance of Budgeting on small business performance.

Table1: Perception of Entrepreneurs on the Effect of Budgeting on Business Performance

\begin{tabular}{|c|c|c|c|c|c|}
\hline \multirow{3}{*}{$\begin{array}{l}\frac{\text { Responses }}{\text { Budgeting system is relevant to }} \\
\text { Entrepreneur business }\end{array}$} & \multicolumn{2}{|c|}{ AGREED } & \multirow{3}{*}{$\begin{array}{l}\text { UNDECIDED } \\
\text { U } \\
06 \\
5.77 \%\end{array}$} & \multicolumn{2}{|c|}{ DISAGREED } \\
\hline & SA & & & D & SD \\
\hline & $\begin{array}{l}40 \\
38.46 \%\end{array}$ & $\begin{array}{l}49 \\
47.12 \%\end{array}$ & & $\begin{array}{l}07 \\
6.73 \%\end{array}$ & $\begin{array}{ll}02 \\
1.92 \%\end{array}$ \\
\hline $\begin{array}{l}\text { Business regularly evaluate the } \\
\text { effectiveness of budgeting system }\end{array}$ & $\begin{array}{l}36 \\
34.61 \%\end{array}$ & $\begin{array}{ll}52 \\
50.0 \%\end{array}$ & $\begin{array}{ll}03 \\
2.88 \%\end{array}$ & $\begin{array}{l}08 \\
7.69 \%\end{array}$ & $\begin{array}{ll}05 \\
4.81 \%\end{array}$ \\
\hline
\end{tabular}


In Fluence of budgeting system on Entrepreneurial Business performance: perspective of Small

\begin{tabular}{|c|c|c|c|c|c|}
\hline $\begin{array}{l}\text { Budgeting system is capable of } \\
\text { influencing Entrepreneur Business } \\
\text { performance }\end{array}$ & $\begin{array}{l}32 \\
30.76 \%\end{array}$ & $\begin{array}{l}48 \\
46.15 \%\end{array}$ & $\begin{array}{l}08 \\
7.65 \%\end{array}$ & $\begin{array}{l}12 \\
11.54 \%\end{array}$ & $\begin{array}{l}04 \\
3.855 \%\end{array}$ \\
\hline $\begin{array}{l}\text { Budget gives direction of business } \\
\text { performance }\end{array}$ & $\begin{array}{l}25 \\
24.04 \%\end{array}$ & $\begin{array}{l}44 \\
42.31 \%\end{array}$ & $\begin{array}{l}11 \\
10.57 \%\end{array}$ & $\begin{array}{ll}08 \\
7.69 \%\end{array}$ & $\begin{array}{l}16 \\
15.38 \%\end{array}$ \\
\hline $\begin{array}{l}\text { Budgeting system is not so important } \\
\text { in the performance of the business }\end{array}$ & $\begin{array}{l}14 \\
13.46 \%\end{array}$ & $\begin{array}{l}05 \\
6.25 \%\end{array}$ & $\begin{array}{l}06 \\
5.77 \%\end{array}$ & $\begin{array}{l}51 \\
49.04 \%\end{array}$ & $\begin{array}{l}28 \\
26.92 \%\end{array}$ \\
\hline
\end{tabular}

\section{Source: Field Survey 2014}

Relationship between Budgeting process and Business Performance

From the table 2, it can be seen that 76.92\% agreed that There is correlation between Budgeting and Entrepreneur financial activities, $15.34 \%$ disagreed while $7.69 \%$ were neutral, showing that There is correlation between Budgeting and Entrepreneur financial activities. In addition ${ }^{` 69.21 \%}$ agreed that Budgeting method serve as tool of Measuring Business performance and $20.19 \%$ disagreed while $10.6 \%$ were neutral an indication that Budgeting method serve as tool of Measuring Business performance. 66.34\% agreed that Capacity of Budgeting method create Entrepreneurship growth, 25.0\% disagreed while 8.65\% were neutral. Analysis from Table2 (q1-q3) also support significance relationship between Budgeting and business Financial Performance.

Table 2: Relationship between Budgeting process and Business Financial Performance

\begin{tabular}{|c|c|c|c|c|c|}
\hline \multirow[t]{2}{*}{ Responses } & \multicolumn{2}{|l|}{ Agreed } & \multirow{2}{*}{$\begin{array}{l}\text { Undecided } \\
\text { U }\end{array}$} & \multicolumn{2}{|c|}{ Disagreed } \\
\hline & & A & & D & SD \\
\hline $\begin{array}{l}\text { There is a link between } \\
\text { Budgeting } \quad \text { system and } \\
\text { Entrepreneurial activities }\end{array}$ & $\begin{array}{l}20 \\
19.23 \%\end{array}$ & $\begin{array}{l}60 \\
57.69 \%\end{array}$ & $\begin{array}{l}08 \\
7.69 \%\end{array}$ & $\begin{array}{l}12 \\
11.54 \%\end{array}$ & $\begin{array}{l}04 \\
3.84 \%\end{array}$ \\
\hline $\begin{array}{l}\text { Budgeting method serve as tool } \\
\text { of Measuring Business } \\
\text { performance. }\end{array}$ & $\begin{array}{l}24 \\
23.06 \%\end{array}$ & $\begin{array}{l}48 \\
46.15 \%\end{array}$ & $\begin{array}{l}18 \\
12.30 \%\end{array}$ & $\begin{array}{l}18 \\
12.30 \%\end{array}$ & $\begin{array}{l}08 \\
7.69 \%\end{array}$ \\
\hline $\begin{array}{l}\text { Effective Budgeting system } \\
\text { compels performance and thus } \\
\text { create Entrepreneurship growth }\end{array}$ & $\begin{array}{l}14 \\
12.98 \%\end{array}$ & $\begin{array}{l}55 \\
53.36 \%\end{array}$ & $\begin{array}{l}09 \\
7.21 \%\end{array}$ & $\begin{array}{l}20 \\
19.23 \%\end{array}$ & $\begin{array}{l}06 \\
3.36 \%\end{array}$ \\
\hline
\end{tabular}

Source: Field Survey 2014

Test of Hypothesis

Ho: There is no significant relationship between budgeting system and business performance.

The result of the Chi-square analyzed to measure discrepancies between the observed and expected frequency as well as the level of significance of the tested hypothesis as regard findings from Tables 3 presented below. Statistically; findings from the table indicates that expected value is greater than observed value, with calculated $\mathrm{X}^{2}$ cal 49.13 being greater than tabulated $\mathrm{X}^{2}$ tab 13.28 , with this analysis it conclude that the expected value remain significant at a critical level of 99\%;Collectively; we reject null hypothesis stated earlier: There is no significant relationship between budgeting process and business financial performance. due to the result we accept alternative hypothesis that: There is significant relationship between budgeting system and small business performance

Table3: Chi-Square table of Relationship between budgeting system and Small business performance.

\begin{tabular}{|l|l|l|l|l|}
\hline $\mathbf{O}$ & $\mathbf{E}$ & $\mathbf{O - E}$ & $(\mathbf{O - E})^{\mathbf{2}}$ & $(\mathbf{O - E}) \boldsymbol{~}^{\mathbf{2}} / \mathbf{E}$ \\
\hline 223 & 145.6 & 77.4 & 5990.76 & 4.115 \\
\hline 345 & 145.6 & 199.4 & 39760.36 & 27.308 \\
\hline 41 & -45.6 & -104.6 & 10941.16 & 7.515 \\
\hline 62 & 145.6 & -83.6 & 6988.96 & 4,800 \\
\hline 57 & 145.66 & -88.6 & 7849.96 & 5.392 \\
\hline $\mathbf{7 2 8}$ & $\mathbf{7 2 8 . 0}$ & \multicolumn{4}{|l|}{} & $\mathbf{4 9 . 1 3}$ \\
\hline
\end{tabular}

Source: Authors computation 2014

\section{Conclusion}

The result of the tested hypothesis shows that there is a significant relationship between budgeting practices and small business performance. Therefore small business performance and success of any entrepreneur depends on effective budgeting system. In view of the above finding the following recommendations could be useful: 
$>\quad$ Entrepreneurs must have a clear financial goal in mind, which will assists in shaping a broader business strategy for the year, also provides a sense of purpose for business.

$>\quad$ Entrepreneurs should take proper care to evaluate the government budget and identify policies that are hindrance and which can equally impede the organisation policy. This will serve as an aid to proper budgeting and will discourage over/under budgeting.

\section{REFERENCES}

[1]. Adelaja, M. (2006). SMEDAN Begins Establishment of BSCs, BICs nationwide. NACCIMA News, May/June 2006, No. 70, pp. 3 .

[2]. Adediran A. Samson, Josiah Mary, Bosun-Fakunle Yemisi and Imuzeze Obehi Erekpitan. (2012). The impact of working capital management on the profitability of small and medium scale enterprises in Nigeria. Research Journal of Businesses Management, Page 61-69.

[3]. Akande, O.O (2005) Effective financing of small/medium scale enterprises (SMEs) as an impetus for poverty Alleviation in Nigeria: an analytical approach. International journal of economics and development issues, development universal consportia vol $5 \mathrm{~N} 1$ and $2 \mathrm{pp} 1-13$

[4]. Akande, Olusola O. (2011). Accounting skill as a performance factor for small businesses in Nigeria. Journal of emerging trends in economics and management sciences (JETEMS), page 372-378.

[5]. Akanji O.O (2006): "Microfinance as a strategy for poverty reduction" CBN ECONOMIC AND FINANCIAL REVIEW volume 39 , No4

[6]. Akintoye I.R. and Oladejo M.O (2008): "Theory of Micro Enterprises. The Nigeria Experience”, International Journal of Social Sciences, University of Uyo, Akwa Ibom state Nigeria, Vol.3 No 7. ‘

[7]. Almus, M (2004) the shadow of death. "An empirical analysis of the pre-exiting performance of new German firms". Small business economics 23,189201.

[8]. Anwatu Rob, (2006). Microeconomics Environments, NACCIMA News, May/June 2006, No. 70, pp. 3.

[9]. Asaolu, T. O.(2004): Evaluation of the performance of the Cooperative Investment and Credit Societies (CICS) in financing Small-Scale Enterprises (SSEs) in Osun State, Nigeria.

[10]. Audretsch, D.B. and M. Keilbach (2004): Does Entrepreneurship Capital Matter? Entrepreneurship Theory and Practice (Fall), $419-429$.

[11]. Basu, A, Balvy R, Yulek, M (2004): Microfinance in Africa: Experience and Lessons from IMF. AN IMF Working paper

[12]. Chen .j. and Williams (1999)," the determination of business failure in US low Technology and High technology industries" Applied Economics 31(12), 1551-1562

[13]. Eker, M.(2006). The impact of budget participation on managerial performance via organizational commitment: a study on the top 500 firms in turkey. Ankara Universitesi SBF Dergisi, page 118-136.

[14]. Francis Enya (2012). The influence of financial planning and control on effectiveness of business organizations. Multidisciplinary Journal of Research Development Volume 18 No 1.

[15]. Ishola R.A (2008). Budgeting and Budgetary Control for Improved Performance, Finance and Administrative services, page 1421.

[16]. Karunananda and Jayamaha (2010). Financial practices and performance of small and medium- sized enterprises in Sri Lanka. Wayemba University and University of Kelanya, Sri Lanka.

[17]. Morris G. Danielson, Jonathan A. Scott (2006). The capital budgeting decisions of small businesses, Page 1-18.

[18]. Naruanard Sarapaivanich (2003). the use of financial information in financial decisions of SMEs in Thailand $16^{\text {th }}$ Annual Conference of Small Enterprise Association of Australia and New Zealand.

[19]. Okafor, R (2012). Financial management practices of small firms in Nigeria: Emerging tasks for the accountant. European Journal of Business and Management, Vol 4. Page 159-169.

[20]. Ogundana M. O. (2012). The impact of budget on organizational financial performance (a case study of the Nigerian bottling company plc Ilorin plant), Page 6-20.

[21]. Oladejo M.O (2008): "Micro Businesses and Entrepreneurship development; explanatory Accounting procedure”, in Proceedings of International conference on Socio-economic policies \& MDGs in Africa, Faculty of Management sciences, AAU, Akungba Akoko, ondo state, pp, 366-372.

[22]. (OECD) (2004), Organisation for Economic Co-operation and Development: Effective Policies for Small Business; a guide for the policy review process and strategies plans for Micro, Small and Medium Enterprise Development.

[23]. Otawale Fatoki, (2010). An investigation into the financial management practices of new micro enterprises in South Africa, Kamla - Raj. Page 179.

[24]. YangQi (2010). The impact of the budgeting process on performance in small and medium sized firms in china, University of Twenth. Page 23-50

[25]. Storey, D.J (1994) understanding the small business sector. Routledge, London

[26]. Sule, E.I.K (1986). "Small scale industries in Nigeria: concepts, Appraisal of government policies and suggestion solution to identified problems" economic and financial review vol.24, No4, Central Bank on Nigeria

[27]. Van Stel, A. J., and D. J. Storey (2004): The link between firm births and job creation: Is there a up as tree effect? Regional Studies, 38(8), pp 893-909. 